\title{
ANALISA CLUSTERING PHISING DENGAN K-MEANS DALAM MENINGKATKAN KEAMANAN KOMPUTER
}

\author{
Suhardi Rustam \\ Suhardirstm@gmail.com \\ Universitas Ichsan Gorontalo
}

\begin{abstract}
Abstrak
Hampir setiap aksi kejahatan di siber merupakan suatu kondisi mengenai aktivitas kriminal dengan menggunakan komputer atau jaringan komputer sebagai alat bantu dan juga sebagai target. Penipuan di website akademik yang paling memiliki resiko. Aksi Phishing ini semakin marak terjadi.Tercatat secara global, jumlah penipuan bermodus phising $42 \%$ dari modus selain phising yang dinyatakan dalam website Anti-Phishing Working Group (APWG) dalam laporan bulanannya, mencatat ada 12.845 e-mail baru dan unik serta 2.560 situs palsu yang digunakan sebagai sarana phishing, Selain terjadi peningkatan kuantitas, kualitas serangan pun juga mengalami kenaikan, perlu adanya usaha yang dilakukan oleh para administrator jaringan dalam meningkatkan pengawasan dalam memonitoring aktivitas di jaringan, dalam aksi pencurian data akan melakukan aksi memanipulasi seseorang dengan tampilan situs web tertentu. Dalam penelitian ini sekumpulan dataset akan diklasterisasi menggunakan k-means, algoritma K-Means akan mengelompokan dataset, menghasilkan identifikasi pishing yang lebih akurat dan bermutu.dengan hasil penelitian ini iterasi $=10, K-F o l d=2$ nilai index davis bouldin $=0.119$
\end{abstract}

Kata Kunci: Klustering, Phising, K-Means, Keamanan Komputer, Data Mining

\begin{abstract}
Almost the crime in cyber is a condition of criminal activity using computers or computer networks as tools and also as a target. Fraud in academic websites the most at risk. The action of Phishing is on the rise. Recorded globally, the number of fraudulent mode phishing $42 \%$ of the mode in addition to phishing which is stated in the website Anti-Phishing Working Group (APWG) in its monthly report, noting there $12.845 \mathrm{e}$-mail new and unique as well as 2.560 a fake site that is used as a means of phishing, in Addition to increase the quantity, the quality of the attacks is also increasing, the need for the work done by the network administrator in improving surveillance in monitoring activity on the network, in the action of data theft will perform the action of manipulating someone with the appearance of a particular web site. In this study a set of datasets will be clustering using k-means, K-Means algorithm will classify the dataset, resulted in the identification of phishing that is accurate and certifiable. With the results of this research iteration=10, the K-Fold=2 the of the Bouldin Davis index $=0.119$.
\end{abstract}

Keywords: Clustering, Phishing, K-Means Clustering, Computer Security, Data Mining

\section{Pendahuluan}

Hal yang merisaukan dari perkembangan teknologi informasi yang senantiasa berubah serta cepatnya dari perkembangan software, keamanan merupakan suatu isu yang sangat krusial dan setiap orang mempertaruhkan waktu dan biaya untuk melindungi data privasi di internet[1], mahalnya biaya perlindungan data baik itu perlindungan fisik, data maupun aplikasi. Hampir seluruh aktivitas seharihari di tuangkan ke dalam internet, interaksi dengan internet dengan memberikan data pribadi pada saat memiliki akun tertentu yang terhubung ke data global. dan Masalah keamanan dan kerahasiaan data merupakan salah satu aspek penting dari suatu sistem informasi. Keamanan komputer adalah suatu cabang teknologi yang dikenal dengan nama keamanan informasi yang diterapkan pada komputer. Sasaran keamanan komputer antara lain adalah sebagai perlindungan informasi terhadap pencurian atau korupsi, atau pemeliharaan ketersediaan.

Aksi Phishing ini semakin marak terjadi.Tercatat secara global, jumlah penipuan bermodus phising $42 \%$ dari modus selain phising yang dinyatakan dalam website Anti-Phishing Working Group (APWG) dalam laporan bulanannya, mencatat ada 12.845 e-mail baru dan unik serta 2.560 situs palsu yang digunakan sebagai sarana phishing.Selain terjadi peningkatan kuantitas, kualitas serangan pun juga mengalami kenaikan. Artinya, situs-situs palsu itu ditempatkan pada server yang tidak menggunakan protokol standar sehingga terhindar dari pendeteksian, perlu adanya usaha yang dilakukan oleh para administrator jaringan dalam meningkatkan pengawasan lalu lintas data di jaringan komputer dengan berbagai cara. Pada penelitian sebelumnya mengatasi ancaman penipuan dengan menonaktifkan 
layanan-layanan komputer di jaringan, penelitian sebelumnya analisa phising hanya membahasa artribut SSL final_state yang dipercaya dan tidak dipercaya oleh penyedia ternama[2].

Penelitian ini akan membahas bagaimana mengidentifikasi Pishing dengan k-means Klustering dan Bagaimana menerapkan Algoritma K-Means Klustering, perlu dibuatkan analisa yang akan menjadi rujukan bagi administrator, pengawas dan perencana jaringan dan system informasi. Selain itu Clustering merupakan metode yang digunakan dalam data mining yang cara kerjanya mencari dan menglompokkan data mempunyai kemiripan karakteristik antara data satu dengan data lainnya yang telah diperoleh. Ciri khas dari teknik data mining[3]. Metode clustering yang mempunyai sifat efesien dan cepat yang dapat digunakan salah satunya adalah metode k-means, metode ini bertujuan untuk membuat cluster objek berdasarkan atribut menjadi $k$ partisi.cara kerja metode ini adalah mula mula ditentukan cluster yang akan dibentuk, pada elemen pertama dalam tiap cluster dapat dipilih untuk dijadikan sebagai titik tengah (centroid), selanjutnya akan dilakukan pengulangan langkah -langkah hingga tidak ada objek yang dapat dipindahkan lagi[4].

kluster merupakan suatu teknik klasifikasi tanpa pengawasan, menurut kriteria kesamaan tertentu untuk mengklasifikasikan dataset, sehingga objek dari kelas yang mungkin sama, tapi itu adalah keragaman mungkin antara objek yang berbeda, Fungsi yang paling penting dari algoritma klustering mengukur kesamaan untuk menentukan bagaimana menutup dua pola data ke satu sama lain.

Pada algoritma k-means, dikenal membutuhkan parameter input sebanyak $k$, parameter input $k$ sebagai atribut dan membagi sekumpulan $n$, dimana $\mathrm{n}$ adadalh jumlah seluruh atribut objek kedalam parameter input cluster sehingga tingkat kemiripan antar anggota dalam satu cluster tinggi sedangkan tingkat kemiripan atribut dengan anggota pada cluster lain sangat rendah. Kemiripan atribut terhadap cluster diukur dengan kedekatan objek terhadap nilai mean pada cluster atau dapat disebut sebagai centroid cluster atau pusat massa, jika tingkat kemiripan tersebut tinggi maka atribut tersebut dinyatakan sebagait atribut phising dan diberikan saran untuk memonitoring atribut tersebut agar segera diberikan penanganan. Dengan adanya penelitian ini diharapkan pengetahuan administrator, pengawas, pengguna dan perencana jaringan computer semakin meningkat sehingga keamanan jaringan computer dapat ditingkatkan.

\section{Metode}

Metode yang digunakan dalam penelitian ini adalah metode data sampel, alasan menggunakan metode ini adalah bahwa pengambilan dataset dari hasil pencarian dan studi dataset dari kumpulan dataset $\mathrm{UCl}$ yang terbaik. Metode ini sangat sesuai diterapkan dalam penelitian ini karena sebelum uji coba dataset tersebut di preprosessing untuk menghasilkan dataset yang valid sebelum siap diolah dalam program rapidminer 5, RapidMiner sebagai tools data mining memiliki antarmuka yang nyaman, dimana analisa dikonfigurasi dalam sebuah process view. Dalam konsep modular untuk process view ini, setiap langkah analisis digambarkan dengan sebuah operator dalam proses analisis. Operatoroperator ini memiliki port untuk input dan output dimana operator tersebut dapat berkomunikasi dengan operator lain untuk mendapatkan input data atau mengirim data yang telah diubah dan menggenerasi model. Davies-Bouldin Index merupakan salah satu metode yang digunakan untuk mengukur validitas cluster pada suatu metode pengelompokan, kohesi didefinisikan sebagai jumlah dari kedekatan data terhadap titik pusat cluster dari cluster yang diikuti, Evaluasi menggunakan Davies Bouldin Index ini memiliki skema evaluasi internal cluster, dimana baik atau tidaknya hasil cluster dilihat dari kuantitas dan kedekatan antar data hasil cluster[5],dapun skema dalam menggunakan metode data sampel adalah sebagai berikut [6].

\begin{tabular}{|c|c|}
\hline $\begin{array}{l}\text { Diagnosa } \\
\text { Data Sampel }\end{array}$ & $\begin{array}{ll}\text { 1. } & \text { Identifikasi Masalah } \\
2 . & \text { Penentuan metode penelitian } \\
\text { 3. } & \text { Perumusan Masalah } \\
\text { 4. } & \text { Menentukan Tujuan }\end{array}$ \\
\hline $\begin{array}{l}\text { Perencanaan } \\
\text { Data sampel }\end{array}$ & $\begin{array}{l}\text { 1. Identifikasi variabel data sampel } \\
2 . \\
\text { 3. Penentuan jumlah data sampel } \\
\text { Menentukan alur }\end{array}$ \\
\hline $\begin{array}{l}\text { Pengolahan } \\
\text { Data sampel }\end{array}$ & $\begin{array}{l}\text { 1. Pembersihan data (preprosessing) } \\
2 . \\
\text { 3. Pengolahan Data } \\
\text { Pembentukan prototype }\end{array}$ \\
\hline Evaluasi & $\begin{array}{ll}\text { 1. Pengujian data } \\
\text { 2. Kesimpulan }\end{array}$ \\
\hline
\end{tabular}

Gambar 1 skema metode data sampel 


\subsection{Diagnosa Data Sampel}

Dalam tahapan ini dimulai dari Identifikasi masalah merupakan proses awal bagaimana memahami persoalan yang ada, seringnya/meningkatnya gangguan/ancaman penipuan melalui jaringan internet, hal ini yang menjadi persoalan bagi administrator/pengawas/perencana jaringan komputer saat ini, selanjutnya pada penentuan metode penelitian yang dilakukan dalam penelitian saat ini adalah metode data sampel, metode ini melakukan pengujian terhadap sejumlah data atau keseluruhan data sampel, pembersihan atribut/preprosessing juga di gunakan untuk menggurangi nilai atribut yang tidak valid dalam data sampel, sehingga metode ini layak digunakan, juga tahap lain yaitu perumusan masalah dalam penelitian ini merumuskan masalah yaitu bagaimana menerapkan algoritma k-means dalam menganalisa clustering phising, adapun tujuan penelitian ini adalah mampu mengklastering data phising dengan metode k-means.

\subsection{Perencanaan Data Sampel}

Untuk indentifikasi variabel data sampel dalam perencanaan ini yaitu menentukan variabelvariabel yang memiliki kaitan yang dekat antar variabel dan kemudian dari data sampel akan ditentukan besaran jumlah data dari 500 s/d 1000 record data.

\subsubsection{Penentuan alur}

Berikut ini merupakan alur penelitian

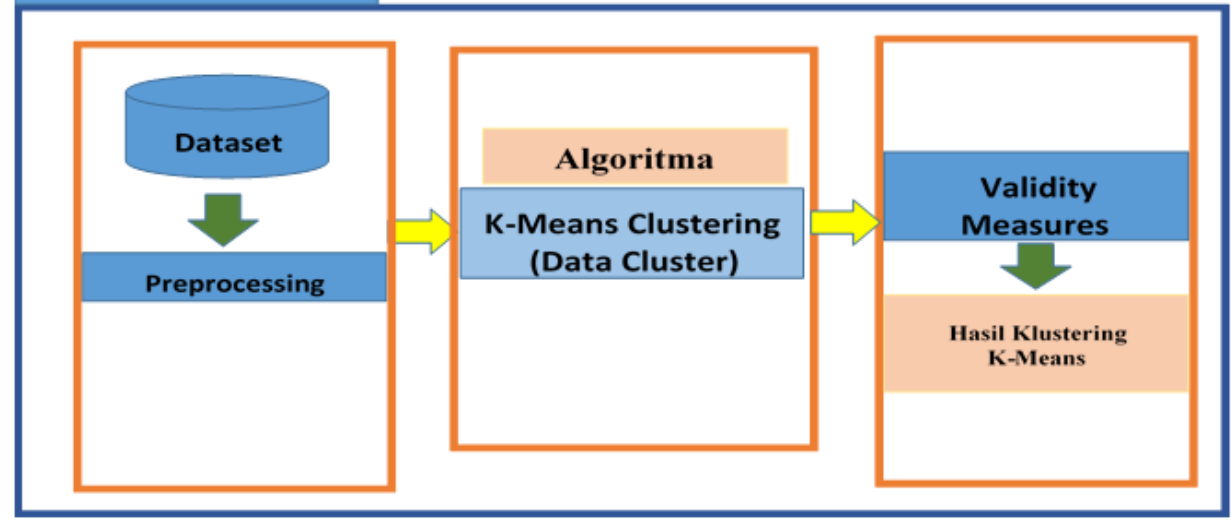

Gambar 2 alur penelitian

\subsection{Pengolahan Data Sampel}

Penting diperhatikan dalam pengolahan data sampel yaitu pembersihan data atau yang sangat dikenal preprosessing Dataset yang akan diproses terlebih dahulu dilakukan preprosessing untuk membersihkan atribut yang tidak berkaitan atau nilai dari atribut yang tidak valid, selanjutnya adalah pengolahan data dimana pengolah data merupakan pengecekan kembali nilai dan atribut data sehingga bisa diolah dengan tool rapidminer 5, kesiapan tahap inilah yang harus diperhatikan sebelum pembentukan prototype, Prototype merupakan gambar tampilan yang akan dibuat.

\subsection{Pengujian data}

Pengujian data dengan menggunakan tool rapidminer 5 secara berulang dengan menggunakan parameter yang disediakan rapidminer 5 sampai menghasilkan nilai maksimal.

\section{Hasil dan Pembahasan}

\subsection{Implementasi Algoritma K-Means}

Dapat dilihat pada gambar 3 di bawah merupakan diagram alur dari metode k-means yang digunakan dalam pengelompokkan pishing, pada umumnya kinerja metode k-means secara berurutan adalah sebagai berikut :

1. Menentukan banyaknya cluster $(k)$

2. Menentukan centroid

3. Apakah nilai centroidnya berubah? a.Jika ya, hitung jarak data dari centroid b.Jika tidak, selesai.

4. Mengelompokkan data berdasarkan jarak terdekat 


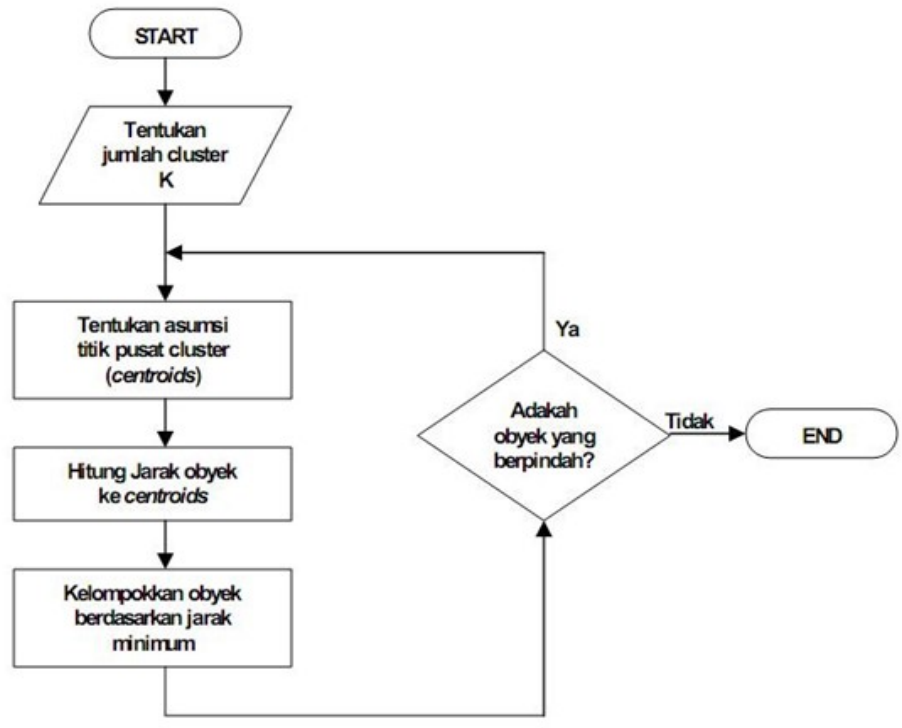

Gambar 3 Alur Implementasi Algoritma K-Means

\subsection{Preprocessing}

Preprocessing Pada sebuah penelitian data mining terdapat data yang akan diolah dengan metode yang telah ditentukan sebelumnya, pada penelitian ini data yang digunakan adalah dataset pishing yang akan diolah menggunakan metode k-means untuk mengelompokkan data variable serangan tersebut kedalam kelompok variabel yang "sering" dan "tidak sering" berdasarkan beberapa variabel inputan. Variabel inputan yang digunakan dalam pengelompokkan pishing tersebut adalah Having_IP_Address, Shortining Service, Having_At_Symbol, double_slash_redirecting, Favicon, port, on_mouseover, RightClick, Iframe, Google_Index dan Statistical_report. Kemudian variabel tersebut akan diolah menggunakan metode k-means yang kemudian menghasilkan output kelompok pishing.

Data penelitian yang sedang dilakukan merupakan data pishing sebanyak 300 data yang akan dikelompokkan ke dalam cluster "sering(C1)" dan cluster "tidak sering (C2)" pengelompokkan tersebut diolah menggunakan algoritma k- means. Sampel dari dataset pishing dapat dilihat pada tabel 1 di bawah ini.

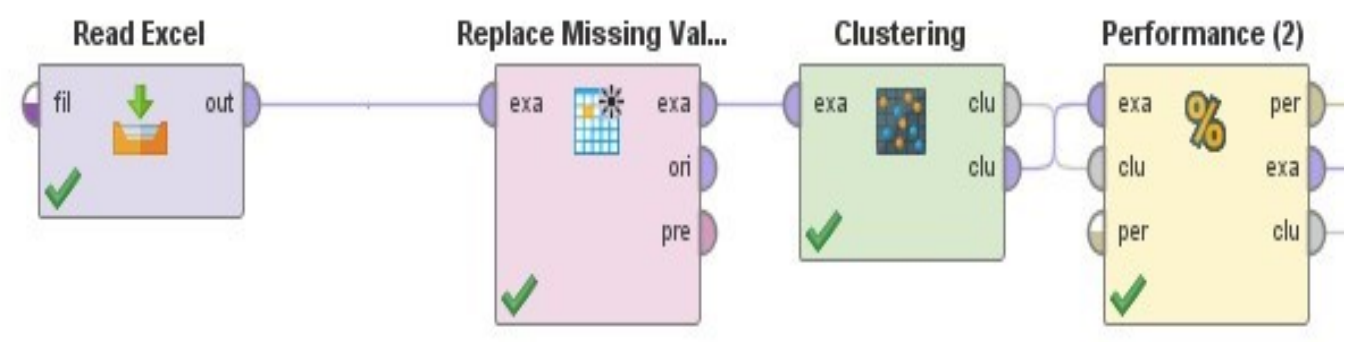

Gambar 4 Model K-Means pada Rapidminer

Gambar 4 Model K-Means pada Rapidminer, yang di mulai dari pembacaan dataset yang dimasukkan melalui Microsoft excel yang telah diklasifikasi variable dan menghilangkan outlier gangguan nilai untuk memudahkan pembacaan nilai numeric, Replace Missing Value merupakan operator untuk membersihkan nilai data ke dalam tipe data numeric, operator Clustering merupakan model operator untuk metode K-Means untuk menghitung jarak dari setiap kluster data, operator Performance untuk pengukur validasi dengan menggunakan metode index davis bouldin. 


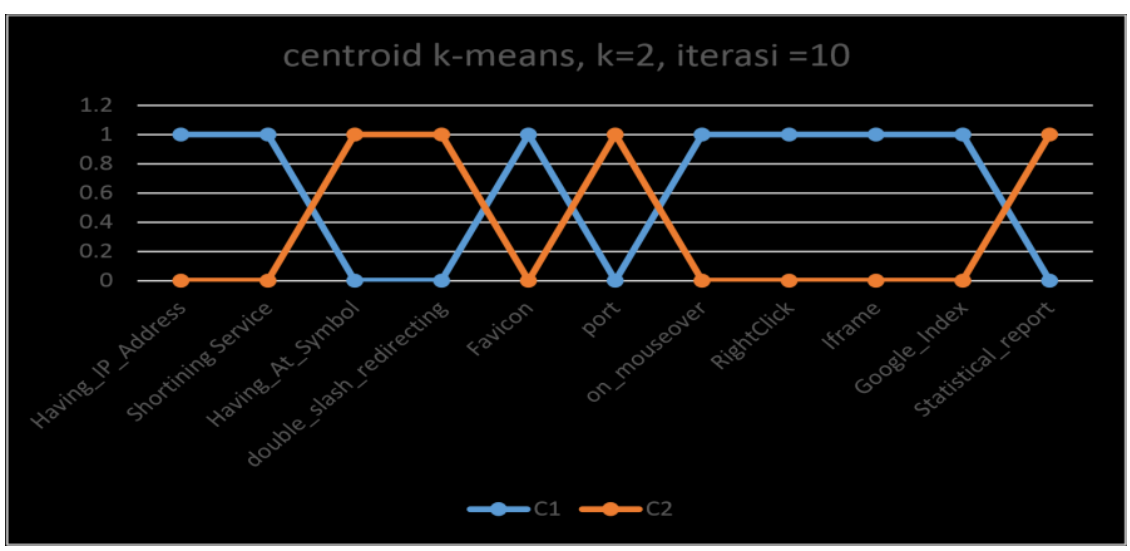

Gambar 5 Grafik Centroid K-Means Klustering

\subsection{Analisis dan Validasi Hasil}

Tabel 1 Hasil Validasi K-Means

\begin{tabular}{|c|c|c|c|}
\hline Validasi & Iterasi & K & K-Means \\
\hline \multirow{4}{*}{ Davie Bouldin Index } & 2 & 2 & 2.021 \\
\cline { 2 - 4 } & 3 & 2 & 1.915 \\
\cline { 2 - 4 } & 4 & 2 & 2.113 \\
\cline { 2 - 4 } & 5 & 2 & 1.991 \\
\cline { 2 - 4 } & 6 & 2 & 2.811 \\
\cline { 2 - 4 } & 7 & 2 & 2.132 \\
\cline { 2 - 4 } & 8 & 2 & 2.211 \\
\cline { 2 - 4 } & 9 & 2 & 1.071 \\
\cline { 2 - 4 } & 10 & 2 & 0.119 \\
\hline
\end{tabular}

Tabel 1, Hasil Validasi Metode K-Means, dengan validasi Index Davis Bouldin sebagai Performance, iterasi (banyaknya dataset di jalankan) 10, dengan K-Fold (pembagi kluster) 2 maka hasil validasi metode k-means adalah 0.119. hal ini juga ditunjukan pada gambar 6 Grafik Validasi K-Means, Dbi (Davies bouldin index), kluster yang memiliki nilai Dbi terendah dianggap sebagai kluster yang paling tepat. seperti di bawah ini.

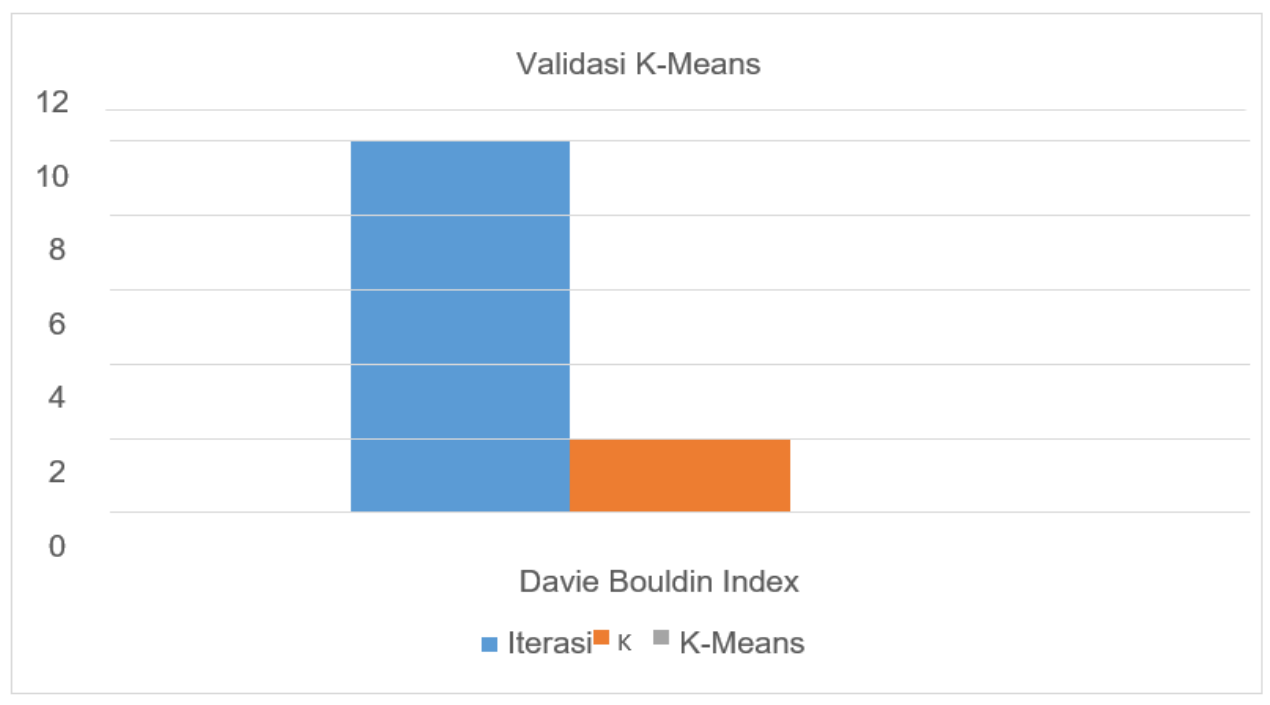

Gambar 6 Grafik Validasi K-Means 


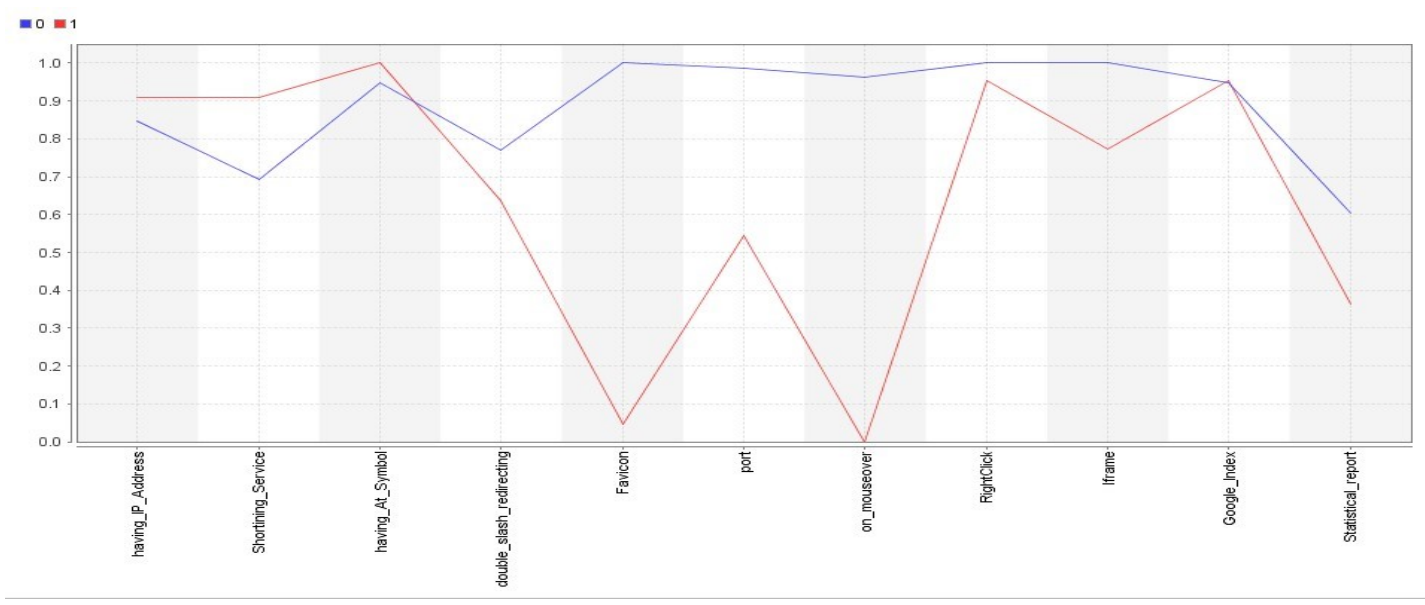

Gambar 7 Plot K-Means Klustering

Gambar 7 Plot K-Means Klustering, merupakan hasil klustering dataset pisihing dengan cluster_0 dan cluster_1.

\subsection{Hasil Uji Coba}

Tabel 2 Hasil Eksperimen Data Pishing

\begin{tabular}{|c|c|c|c|c|c|c|c|c|}
\hline Dataset & Metode & no & Nama Variabel & $\mathrm{C} 1$ & $\mathrm{C} 2$ & Iterasi & K-Fold & $\begin{array}{l}\text { Index davies } \\
\text { Bouldin (IDB) }\end{array}$ \\
\hline \multirow{11}{*}{ Phising } & \multirow{11}{*}{ K-Means } & 1 & Having_IP_Address & 1 & 0 & \multirow{11}{*}{10} & \multirow{11}{*}{2} & \multirow{11}{*}{0.119} \\
\hline & & 2 & Shortining Service & 1 & 0 & & & \\
\hline & & 3 & Having_At_Symbol & 0 & 1 & & & \\
\hline & & 4 & double_slash_redirect ing & 0 & 1 & & & \\
\hline & & 5 & Favicon & 1 & 0 & & & \\
\hline & & 6 & port & 0 & 1 & & & \\
\hline & & 7 & on_mouseover & 1 & 0 & & & \\
\hline & & 8 & RightClick & 1 & 0 & & & \\
\hline & & 9 & Iframe & 1 & 0 & & & \\
\hline & & 10 & Google_Index & 1 & 0 & & & \\
\hline & & 11 & Statistical_report & 0 & 1 & & & \\
\hline
\end{tabular}

Tabel 2 hasil Eksperimen Data Pishing, dengan Dataset Pishing, menggunakan metode KMeans, iterasi $=10, \mathrm{~K}-\mathrm{Fold}=2$ menghasilkan index davis bouldin $=0.119$, dengan pengukuran ini maka Dataset Pishing memiliki validasi mendekati dengan 0 maka hasil nilai index davis bouldin $=0.119$ memiliki informasi yang lebih baik.

\section{Kesimpulan dan Saran}

Berdasarkan hasil eksperimen dan pembahasan, maka dengan ini dapat simpulkan bahwa pengujian model dengan menggunakan algoritma k-means untuk data pishing mendapatkan nilai IDB (davies bouldin index $)=0.119$, $\mathrm{k}$-fold $=2$, iterasi $=10$ sebagai nilai ukur terhadap validasi data pishing . Maka pengujian model dengan menggunakan k-means dengn IDB (davies bouldin index) adalah Lebih baik dalam memberikan pemecahan untuk permasalahan identifikasi pishing untuk keamanan computer yang lebih akurat dan bermutu.

\section{Terima Kasih}

Saya mengucapkan banyak terima kasih atas sharing ilmu dari rekan sesama dosen dan peneliti pemula di fakultas ilmu komputer universitas ichsan gorontalo 


\section{Daftar Pustaka}

[1] Musriha, Gilang R. 2014. Pengaruh Intensitas Pemakaian Internet Terhadap Penggunaan Internet untuk Berbelanja Online yang Dimoderasi oleh Consumer Innovativeness Di Surabaya

[2] Salim, Tomy. 2017. Data Mining Mengidentifikasi Website Phising Menggunakan Algoritma C.45. Jurnal TAM (Technology Acceptance Model) Volume 8

[3] Arora, P., Deepali, D., dan Varshney, S. 2015. Analysis of K-Means and KMedoids Algorithm For Big Data. International Conference on Information Security \& Privacy (ICISP2015), (hal. 507-512). Nagpur,India.

[4] Agusta Yudi.2007. K-Means - Penerapan, Permasalahan dan Metode Terkait. Jurnal Sistem dan Informatika Vol. 3

[5] Bates, A. \& Kalita, J. 2016. Counting clusters in twitter posts. Proceedings of the $2^{\text {nd }}$ International Conference on Information Technology for Competitive Strategies, pp. 85

[6] Hasibuan, A Zaenal .2007. Metodelogi Penelitian Pada Bidang Ilmu Komputer dan Teknologi Informasi. 20 Juli 2018 